\title{
Title:
}

Per diem payments as a form of censorship and control: the case of Guinea-Bissau's journalism

Author: Susana Sampaio-Dias

Author's details:

Susana Sampaio-Dias

Department of Journalism

School of Film Media and Communication

University of Portsmouth

Milldam, LB 3.02

Burnaby Road

Portsmouth, PO1 3AS

United Kingdom

Tel: +442392846096

E-mail: susana.sampaio-dias@port.ac.uk 


\section{Per diem payments as a form of censorship and control: the case of Guinea- Bissau's journalism}

This article discusses the habit of politicians paying journalists per diem rates in exchange for media coverage. Although bribery and money incentives have been studied as practices that compromise the ethics of journalism in several African countries, this paper researches Guinea-Bissau as an example and establishes a distinction. Unlike bribery, the widespread payment of these stipends is legal, but it is chronically damaging for freedom of expression and professional integrity. Drawing on interviews, focus groups and ethnographic observation with professionals from national, local and community media, this paper documents the precarious state of journalism in Guinea-Bissau, particularly the sector's acute lack of financial resources and meagre wages. News sources, and dominantly the government and parties, organise multiple events, attracting coverage in exchange for remuneration. Accepting these payments is, for many journalists, the only possible mode of subsisting, despite compromising their independence. News coverage is consequently saturated with propaganda, and forms of investigative journalism are rare. This article argues that the payment of per diem rates, accepted as legitimate and common practice in several other countries, has led to a pervasive control of journalism.

\section{KEYWORDS}

Brown envelope journalism; Corruption; Guinea-Bissau; Per diem; Pluralism; Poverty; Press freedom; Press regulation; Professional ethics; 


\section{Introduction}

In 2015, Aljazeera travelled to Lagos, Nigeria, one year after 116 people were killed when a church roof collapsed in outskirts of the city. The broadcaster reported the trial that followed with a specific angle: how Nigerian press was providing a substantially different coverage. The piece aimed to address a syndrome of media bribery known as 'brown envelope journalism', and unveil why the national media were altering the narration of the story. It was believed that the construction violated building regulations with four illegally added storeys. The Nigerian newspaper headlines, yet, speculated about a Boko Haram attack, or about a 'mysterious aircraft hovering around the church' before the collapse. Aljazeera interviewed two Nigerian reporters, Nicholas Ibekwe and Kadaria Ahmed, who broke yet, another story: that the media was bribed by the owner of the Evangelist church, pastor TB Joshua, to omit the church's negligence. The piece explained the phenomenon of bribery mentioning that Nigerian journalists were among the worst-paid reporters in Africa. Media adviser Femi Adesina, featured in the report, explained:

There is a saying that 'the music hunger plays in your stomach makes you deaf to reason.' You don't preach ethics to a hungry man. Therefore when journalists are not paid, they are prone to being compromised. (in Aljazeera, December 27, 2015)

For many African journalists, situations like this do not come as a surprise. In media research, there has been a growing interest in studying bribery and corruption in journalism not just in Africa, but globally. An array of studies links this phenomenon with discussions about professionalism and ethics, and often relates the causes of corruption with contexts of extreme poverty and precarious working conditions (Wahl-Jorgensen and Cole 2008; Skjerdal 2010).

This article will be extending the discussion about the implications of bribery in journalism, highlighting, however, an essential distinction for other subtler forms of control. The primary aim of this article is to investigate how per diem payments, acknowledged as legal, can similarly hinder the freedom of information, democratic practices and plurality of media contents, like other illicit forms of corruption. Per diem payments are smaller fixed amounts of money paid by sources in exchange for media presence or coverage of an event. Differently from brown envelope payments, these are overtly paid, expected as an addition to journalists' wages, and recognised as inherent to the profession.

There are no studies that specifically isolate and address this type of stipends and its consequences to news pluralism and press freedom, and per diem payments are often muddled in studies about bribery taking place in several countries. This article argues, however, that they constitute a tool for media manipulation and censorship that must not be ignored or understated by 
academics, policymakers and journalists. The paper draws on the investigation of the media environment in Guinea-Bissau, by conducting extensive qualitative research with journalists. It demonstrates that news workers are aware that, by accepting these payments, there are costs to their independence, that news contents become saturated with propaganda, and that investigative reporting is discouraged and almost inexistent. They recognise that a context of deprivation allows politicians and authorities to manipulate and censor media content. A central argument in this paper is that paying journalist per diem fees translates in a legitimised form of 'cash for coverage' that undermines independent journalism, creating a conflict of interest between the responsibility to provide reliable news to the public and the interests of those who aim to control the news agenda. This dynamic contributes to an unhealthy press system that prevents a free exchange of political ideas (Fair 2013) and an informed public debate within civil society.

\section{Monetary incentives in journalism}

There are various studies describing circumstances when journalists accept incentives to do their jobs. Either referred to as cash for coverage (Kruckeberg and Tsetsura 2003; Ristow 2010) or gift acceptance (Onyebadi and Alajami 2014), since these incentives can be more than just monetary, the phenomenon is explained as not new or geographically exclusive (Sanders 2003; Lodamo and Skjerdal 2009; Ristow 2010; Elahi, 2013). In most cases, the practice is generally known as brown envelope syndrome, in an allusion to the brown envelopes with money that are secretly given by the sources to journalists on a reporting assignment, although in many cases this payment does not come necessarily in a brown envelope. This system implies that government personnel, company executives, and event organisers pay money, all-expenses-paid trips, and other material gifts, to get journalists to cover the events they promote. In either form, this practice is generally seen as a form of bribery and corruption or a 'rot that has plagued' media industry for some time (Ekeanyanwu and Obianigwe 2012).

Despite being recognised as a worldwide phenomenon, academic scrutiny on illegal payments in journalism practices focuses mostly on South East Asia, Eastern Europe, Latin America and Africa. In 2010, a special issue of the journal African Communication Research addressed the theme of 'Bribery and Corruption in African Journalism'. The call for articles, the editors explain, received a popular response, giving them reasons to believe that these bribes and payments were a common presence in African journalism (Skjerdal 2010). Focusing on the African practices and based on an extensive review of research developed by local scholars, Skjerdal (2010) listed the different names, phrases and euphemisms particular to the acts of giving and accepting bribes. In Nigeria, a number of local terms are used like "keske”, "kola”, "goro”, but also some English euphemisms like "family 
support", "better life", and "handshake" are used, translating well how journalists and organisers perceive these monetary incentives. In Ghana, the popular words are "payola" and "soli"; the latter term, Skjerdal explains, is shortened from "solidarity" and implies that this is the sources' mode of expressing sympathy with the precarious situation the journalists work in and therefore extend a helping hand that also reinforces the relationships between the two parties. The local term "ndalama yamatako" in Zambia adds a touch of humour to this list of euphemisms, as it means "money for the buttocks" as the journalists receive a contribution to compensate sitting through press conferences. A similar connotation comes from the Swahili "mshiko", received by Tanzanian and Kenyan journalists to endure the time spent attending to a press conference. If an event will not provide these compensations, Ethiopian journalists call it "derek tabiya", translated as "dry location"; and journalists who, for moral reasons, will not accept brown envelope payments are called "wogami", meaning deviant or conservative, and are seen as a minority (Lodamo and Skjerdal 2009).

In other parts of the world, different practices of bribery and ethical journalistic attitudes have also been receiving increased interest. In a report for the Center for International Media Assistance published in 2010, Ristow mentions the "red envelopes" in China; the "blocking newspapers" in Cambodia that extort money from prominent figures not to publish or to block inconvenient stories; the various forms of cash for favourable coverage in Ukraine known as "jeansa" or in Russia as "zakazukha"; the bribes paid to journalists in Peru known as "mermelada", or jam for journalists and, in Nicaragua, there is a "Day of the Journalists", a day when officials send journalists gifts, food baskets and cash. Further work on the Philippines describes the existence of "ATM journalism" when reporters receive regular payoffs through bank transfers in the names of their spouses or relatives (Hofilena 2004, in Loo 2005).

Whatever form, name or euphemism it takes, academics seem to agree that these are unethical and corrupted practices that demand scholarly attention. The literature further suggests that there are various levels of susceptibility to bribing with some authors laying the responsibility on an individual level, rejecting the practice as a collective act (Kasoma 2009; Ristow 2010; Skjerdal 2010; Onyebadi and Alajmi 2014). In many cases, brown envelope practice is so common that journalists might accept it without fully realising that it implies a compromise of their journalistic principles, or they may be unsure of what constitutes a bribe (Hermawan 2006, in Ekeanyanwu and Obianigwe 2012). The payments are, however, expected in most contexts, journalists ask for it openly, and can even black out events if the payments are refused (Ekeanyanwu and Obianigwe 2010, 2012).

Most research on bribery and corruption seems either to flow into a debate about professionalism and ethics in journalism or to explain the phenomenon as intrinsically associated to contexts of political instability, economic distress and poverty (Wahl-Jorgensen and Cole 2008); some 
research raises a combination of the two debates as causes naturally connected. The problem is worsened by, in certain countries, a lack of ethical codes for the media, and in most contexts an absence of ethics training for journalists, a flawed sense of professionalism and a disquieting laxity of the regulatory bodies (Lodamo and Skjerdal 2009; Onyebady and Alajmi 2014; Eke 2014). Although recognising the problematic side of bribery, journalists often appear to accept it as intrinsic to the profession, justified by their low salaries and poor journalistic training. This seeming contradiction mirrors a discrepancy between theory and practice in African journalism ethics, where unethical practices might coexist with journalists' ethical mindsets (Skjerdal 2018). In countries where bribery is endemic to journalism, media owners also seem to show little concern for the integrity of their newsrooms (Elahi 2013; Onyebady and Alajmi 2014). Academics and press freedom organisations highlight the need to enforce existing ethical codes, and improve the welfare of professionals as a practical way to end this form of collusion that is often seen as a setback for media growth (Nwabueze 2010; Ristow 2010; Ekeanyanwu and Obianigwe 2012; Okoro and Chinweobo-Onuoha 2013; Eke 2014).

\section{Per diem payments in journalism practice}

The effects of paying per diem rates have mostly been scrutinized in the field of international development. These studies emphasise the contradictory role per diem rates play when promoting local participation in training initiatives by swiftly recruiting local participants, but also by undermining the sustainability of such projects. Indeed, those training initiatives that do not include per diem payouts quickly become unpopular or even unattended (Pfeiffer 2003; Sanner and Sæbø 2014). Per diem is the Latin phrase that translates to 'per day' and it is a fixed daily allowance paid by organisations and donors, historically Western, to cover employees' expenses in work-related travels (Sanner and Sæbø 2014). This practice has become popular mainly in development projects during the 1970s and escalated during the 1990s. Pfeiffer (2003), when writing about project participation in Mozambique's healthcare sector, highlighted how one week of per diem yielded higher pay than a month's salary for most workers in the country's health sector; this meant that these fees gradually became an essential component for any field-based project organised by a foreign or national institution. While the stipends provide crucial financial support for local workers, it also encourages a proliferation of seminar initiatives or, as planners and academics called it, a seminaritis (Pfeiffer 2003) or perdiemitis (Sanner and Sæbø 2014). The purpose of the mentioned training projects is then defeated, as the primary goal becomes getting these payments, instead of acquiring specialised training (Ridde 2010). 
In journalism, per diem fees are mentioned in a few publications about practice and ethics. In these, per diem rates are both referred to as a form of concealed brown envelope bribe (Skjerdal 2010) or just as a form of monetary help paid by the news sources together with travel and accommodation costs. Different to more explicit forms of bribery, journalists understand per diem as more of a grey area. Studying the case of Ethiopia, Lodamo and Skjerdal (2009) documented that many workers saw these stipends as an opportunity to get extra income and they saw this as legal practice since it was decided by government tariffs. Although most journalists did not see any issue in receiving this surplus payment, the same research identified that this resulted in an informal contract, where positive coverage was expected.

The payments of per diem also seem to include time and context-specific variables. In Ethiopia, for example, during the 2005 elections, journalists from state media organisations bargained with mayors to get plots of land as a replacement for per diem in exchange of favourable media coverage (Dirbaba 2010). In other cases, there seems not to exist a distinction between bribery and per diem payments. In Cameroon and Chad, elites and politicians pay the gombo in exchange for favourable press (Ndangam 2006). The term refers to a vegetable eaten as porridge, usually dirtying the fingers, and refers to bribes, freebies, and also to per diem fees (Ngangum 2016). This practice initiates a patron-client relationship in which both journalists and sources benefit.

The dynamics of paying, expecting and accepting per diem fees, similarly to more obvious forms of bribery in journalism, are often associated with contexts of deprivation. These stipends are usually of low value. Still, in many countries, the per diem tariff surpasses the journalists' monthly salary (Cagé 2015). Looking at the case of Benin, Grätz (2015) mentioned these payments as one of the several modes of obstructing press freedom. These per diem, he explains, are seen as seductive additional revenue for a class that struggles with the daily survival. The coverage of a press conference organised by a political party, for example, when per diems paid by the public relations departments are expected, is preferred to the coverage of other topics. This results in a mode of self-censorship, as the coverage of events where per diem is paid will most likely result in benevolent news reports. In turn, governments use this form of paid journalism as a more subtle way of media control and censorship.

Despite the payment of per diem being included in academic conversations about corruption in journalism, there is, however, an important distinction to be made. A central argument in this paper is that the following characteristics define the practices of per diem payments in journalism: they carry in their nomenclature a semantic meaning of legitimacy, as the origins of such practices are rooted in and credited by international institutions. Further, as observed in the case of Guinea-Bissau and explained by the journalists interviewed, these rates are fixed, tacitly known, and inspired by the recommended 
rates from institutions such as the World Bank or the United Nations. These incentives are considered legal (or at least not illegal) and are not offered in a concealed manner like other forms of bribery, which may explain the journalists' liberal attitudes to this type of payments (Lodamo and Skjerdal 2009). Despite this seemingly lawful nuance, these payments, I defend, have the potential to be as destructive for journalism and democracy as unlawful practices of bribing. Similar to brown envelope bribes, per diem payments allow the establishment of an informal contract between journalists and their sources, who expect beneficial coverage. This expectation is incompatible with journalistic independence and results therefore in a subtle form of control and censorship. Further, per diem payments bring to light a form of legitimised control that is exempt from accountability.

The distinction between these two modalities of interference in journalism, overt or concealed, needs to be established, but so does the similarity between them. Departing from the characteristics described by Skjerdal's study of bribery (2010), the table below highlights the differences and similarities for both types of monetary incentives in journalism. Although, brown envelopes can also refer to smaller amounts of monetary incentives (Ndangam 2006, 2009; Skejerdal 2010), the denomination 'brown envelope payments' used in this table refers to general forms of bribery.

[Table 1 here]

To the best of my knowledge, no documented evidence locates the early beginnings of the habit of paying journalists per diem in Guinea-Bissau. Many journalists, however, detected this as a problem that heavily taints their professionalism and limits their freedom, as will be explored later in this paper. In this sense, I argue that such forms of manipulation and censorship should not be ignored or underestimated by scholars, policymakers and journalists as, not differently from more apparent forms of corruption, they hinder the freedom of information, democratic practices and plurality of media contents. Thus, the thesis here is that, similarly to bribery and gift giving, paying journalist per diem translates in a legitimised form of 'cash for coverage', that has the potential to undermine independent journalism by creating a conflict of interest between the responsibility to provide reliable news to the public and the interests of those who aim to control the news agenda.

\section{Journalism in Guinea-Bissau: a brief overview}

Guinea-Bissau is a small country in West Africa with a turbulent past and present. Since the independence from Portugal in 1973, the country has witnessed a violent and disruptive democratic transition (Ostheimer 2001). If the post-independence period has shortly made the country look like a 
trendsetter for democracy (Mendy and Lobban 2013), a civil war in 1998-99 and a seemingly endless series of military coups have proven this optimism wrong. This chronic political instability has consequently dragged the country's economic and social structures down. The political vulnerability, together with the country's problematic and unaccounted connection to drug trafficking - GuineaBissau is in the trafficking route from Latin America (Vincent 2007; Chabal and Green 2016), have contributed to a hostile scenario for journalism and media freedom. Similar to earlier periods of political unrest, the latest coup d'état in April 2012 was followed by a temporary news blackout, military censorship and reported cases of threats to journalists. The chilling effect of coercion and intimidations by the military authorities has ever since sustained fear and self-censorship in GuineaBissau's journalism (Freedom House 2014).

The new government elected in 2014 reaffirmed free-speech rights guaranteed by the national 1993 Constitution and by legislation adopted in 2005, to pledge a less intimidating climate for journalism. Still, political fragility persists under the ruling of President José Mário Vaz and, by November 2016 the country had seen five prime ministers in nine months. In 2017, authorities temporarily suspended the political debate radio show Cartas na Mesa on the national radio (RDN), as an attempt to suppress public scrutiny of officials. In the same year, the government also suspended the Portuguese state broadcaster's (RTP) presence in the country. Despite the government arguing that the Portuguese broadcaster disrespected bilateral agreements on media cooperation, the Reporters Without Borders (RSF) condemned the decision, considering it a grave violation of free speech and the right of access to information (2017). These cases were behind the interruption of the slow improvement in Guinea Bissau's press freedom levels over the last years, according to RSF's annual barometer, and the country dropped from the $77^{\text {th }}$ position in 2017 to $83^{\text {rd }}$ in 2018 .

Guinea-Bissau's media landscape encompasses a combination of state media (one radio station, one television broadcaster, one news agency and one newspaper), private media (six radio stations and five newspapers) and community media (thirty-five radio stations and four television broadcasters) (Lopes 2015). Across all sectors, the practice of journalism is plagued by financial uncertainty, scarcity of resources and meagre salaries. Journalists are over-dependent on per diem fees offered by event organisers and news sources in exchange of coverage. These payments supplement their low salaries, resulting in partial coverage and an implicit compromise with the sources, as it will be discussed later in this paper.

\section{Methodology}


This investigation seeks to contribute to the understanding of different journalistic practices and structural contexts around the world, by focusing on a particularly understudied country, GuineaBissau. The research reported here is based on as extensive a range of materials about this country as possible and based on a variety of qualitative research methods. The materials were gathered during two different field trips to Guinea-Bissau in December 2015 and April-May 2016. During these stays, I conducted in-depth interviews with eleven news workers, organised one focus group with fourteen reporters, visited newsrooms and attended the country's first national conference of journalists that took place in December 2015. The present research also draws on the ethnographic observation and notes taken during this meeting. For the contextual description of Guinean journalism, I have collected published and unpublished work by local journalists, academics and institutions.

The in-depth interviews included professionals from several national, local and community media (public and private) and also Guinea-Bissauan correspondents working for international media. Respondents were selected based on the snowball sampling method and aimed to comprise a variety of media organisations and workers with different professional and administrative responsibilities and levels of seniority, including reporters, editors and media managers (two women and nine men). There were no additional criteria for selecting participants, apart from them being practising journalists in Guinea-Bissau. The interviews were propelled by, but not limited to, semi-structured questions and lasted between forty minutes and two hours. The journalists participated in the study with their full consent, and anonymity was given as an option (1). All of the respondents were willing to be identified. Still, as an attempt to minimise potential harm to the interviewees, I decided to keep their identity anonymous.

Additionally, the research draws on data from the analysis of discussions from one focus group of fourteen other Guinea-Bissauan journalists (seven women and seven men) who were initially gathered for an environmental communication workshop (2). Although the aim of the workshop was mainly to discuss environmental news, the dialogues generated were elucidating and commented much on the conditions for the practice of journalism in the country. The discussion took place at the Universidade Lusófona in Bissau, on May $3^{\text {rd }} 2016$. For the participation in the workshop, and with the help and support of the Journalism degree staff at that university, we contacted the directors of several news media and ask them to send us reporters who would be interested in environmental issues. All participants were informed about the aim of the session and the recordings and were aware of the academic research being conducted parallel to the workshop; their contributions ended up being of invaluable importance, and therefore complemented the information collected through the other research methods. For the same reasons explained before, these participant's identifications were kept anonymous (3). 
The ethnographic observation of the country's national encounter of journalists (18-19 December 2015) organised by the recently established association of journalists Ordem dos Jornalistas da Guiné Bissau (OJGB), took place before the interviews and focus group, and flagged up immediately some of the issues that concerned journalists at that point. The notes taken during this event helped to tackle the in-depth interviews departing from the sector's impressions and thus avoiding the dangers of a researcher's pre-conceived expectations. Although the numbers varied across the two days, it is estimated that 60-80 participants attended the congress.

The methodological approach here sought to investigate how news professionals describe their working environment and freedom in a country that has undergone a challenging process of democratisation over the last five decades. The evidence gathered during the interviews and focus group discussions, as well as the observation of the national conference of journalists, provided an opportunity for an elaboration of news professionals' opinions and understandings of journalism practice and its limitations.

\section{The problematic nature of per diem payments in journalism}

Various journalists signalled the problem of impartiality during the National Conference, and also during interviews. The issue of per diem payments compromising the journalists' independence was the focus of one of the panels. The problem was associated with the acute lack of financial resources and meagre salaries: depending on the media company, the base salary for a journalist in GuineaBissau is around 15000-35000 CFA franc (US\$26-62) and the per diem fees are fixed rate of 25000 CFA (US\$44) per job, plus the travel costs, subsistence and accommodation expenses, if necessary, paid by the sources or organisers of the event. Politicians in government and from opposition parties are the most frequently mentioned as paying entities, although international organisations often also pay for these fees. This amount usually increases to 35000 CFA during election times. One broadcast reporter explained how it works, and how politicians are well aware of the journalists' financial distress:

There is no chance for neutrality during elections when you travel to the countryside, for example. Your company has no money for the transportation. So you have to get a ride from the party's car, you have to sit next to the candidate; and even if you're chatting about something else, there will be a moment where he will tell you what he's interested in. He will whisper in your ear in the morning, in the evening, the next day; and you're only human. ... We've opened the precedent here - we don't have money to take our reporters to the countryside, so the one who needs them will pay for this: the transportation, meals, and accommodation. What happens when you're under these conditions? In two or three hours 
you're their friends, and friendship is incompatible with the impartiality principle... The per diem rate is fixed in 25000 CFA for one day, and this is almost our monthly salary... So whoever wants to buy a journalist's conscience pays this amount and then says "Look, you earn very little money, don't you?" they are very smart and say "This is not to buy your conscience", but we know it is; and it's bought then, just by handing the money; and because you're so poorly paid, you take the money quickly and put it in your pocket. Then you don't have the guts to publish anything bad about them and you even add [beneficial] adjectives.

Another broadcast reporter added that, if a journalist tries to resist to this dynamics, they will suffer the consequences in the future: there might not be direct reprehension for resisting and publishing unfavourable information, but the reporter will not be called for any coverage any time soon, and therefore will not have access to this extra form of income:

It is very hard in Guinea Bissau. Even if you try to be unbiased, you end up in a trap... Imagine you are requested to cover some opening in Bafata... they pay you the per diem, give you a lift, pays for your accommodation, your meals, and then you totally depend on them... if you write something that they don't want you to say, next time you're not called.

The majority of newsrooms is affected, as previously mentioned, by the lack of funding, including the state-owned media. This prevents the media companies from being able to afford transportation and any subsistence costs that would allow independent reporting and investigative initiatives. Some of the interviewees, like this state radio reporter, believe that the money should initially come from the media companies and not from the sources:

Usually, the rule should say that, if a journalist is following an event organised by an institution, logically, the radio should fund the reporters' expenses. But that is not what happens. When we travel to other parts of the country, the institution that sought the radio coverage pays the per diem.

As mentioned, by accepting these payments, it is tacitly established that the coverage will not be unfavourable to the source. There were a few anecdotes told by journalists that represent cases where the coverage was not just beneficial, but also distorted, as this journalist who wished to remain anonymous reveals:

There are strong candidates that, when they visit a town, nobody stays at home. But there are other candidates that, when they show up, maybe only twenty people show up. The journalists would then say that hundreds of people were there. On television, sometimes footage from previous rallies is used [to pretend that hundreds of people attended]. Just so you have an idea. 
This radio journalist mentions how episodes like these are detrimental to democracy and people's trust in the media, as they misrepresent the political reality:

This is worrying during the elections. People expect us, as media professionals, to help them with some guidance and help them decide, and we misrepresent everything... If the candidate only has a few people attending their rally, would I be able to report that that candidate had nobody attending their rally? We would all say 'The rally was attended by thousands of people. It was a mega rally', but this wasn't true.

This same journalist also highlighted how this system excludes the representation of smaller parties in the media as, not having the same financial resources as others more powerful, they might not be able to pay for journalists' fees.

Most of the interviewees showed concern about the dependence that sustains the relationship between media and politicians. A reliance aggravated in the public sector media, as a public television reporter explains, that undermines the journalist's commitment and responsibility to contribute to informed citizenry:

... we don't have an editorial line, we end up just responding to the political agenda. That makes our work much harder. ... We end up putting the audience on a second plan, and we end up being manipulated by the politicians. We don't have a daily editorial meeting. We have requests from the politicians, and from there we organise our schedule. We simply prioritise the political coverage; and we are in trouble if we don't attend these requests. There is a lot of pressure from our authorities. We end up forgetting our humanitarian side, our principal mission - that is to respond to the interests of the public, to give a voice to the needed.

The over-reliance on per diem to supplement the insufficient wages in the sector has not just contributed to the misrepresentation of the political class but also given no room for investigative journalism. On the one hand, newsrooms are lacking financial resources to support initiatives beyond the political agenda but, on the other hand, the politicians skilfully make sure to create enough events to keep the journalists busy. As this state-television reporter explained:

You get limited to the requests coming from the government to cover this or that topic. We have no journalism, no creativity... when you lose this freedom, this right, you're being indirectly influenced by the government... the requests [for coverage] are directed to the general-director before getting in the newsroom. What gets down to the newsroom has already been scrutinised and accepted by the minister and by the general-director.

Any attempt to investigate is also discouraged, particularly if the journalist is chasing some lead that is inconvenient to the authorities. As this broadcast journalist reveals, 
There is no investigative journalism here. Firstly, who's going to pay for it? I have no means to investigate. ... And then, when they [authorities] notice that you are investigating something that contradicts what they say or do, or when you're about to expose a secret, you immediately have a problem. You have a problem there. They might not tell you that what you're doing is wrong, but they start threatening you.

As mentioned, the political class takes advantage of this financial vulnerability, and they often show preferences on the journalists they call for any press conference or event. These are the journalists who have no issues in praising the authorities, by publishing positive press. Amongst the journalist class these are called djidiu, a Creole word that means a troubadour who sings to praise someone - the authorities, in this case. For this radio reporter, this collusion between politicians and journalists is a glaring example where press freedom, protected by law, is threatened:

Each politician has his journalists. These are biased journalists. When politicians have their journalists, and journalists are biased, the idea of press freedom is, in fact, not real. With so many coups, so many problems, the biasing of journalism has increased uncontrollably. So the press freedom legislation is not working at all.

Some of the participants in this research were, at the moment of the interviews, in positions of management and others have had this experience in the past. Amongst these, there were some stories of resistance to the established power dynamics between politicians and journalists, as this television reporter and former news director describes:

Some of us who have had directing jobs, we know this practice well, so we would try to hold [newsroom] meetings and try to control this. We would rule out people whom we knew were only after these things [per diems] and selected the most impartial ones...or the ones we thought were more responsible. Then we tried to oversee the news piece, remove [beneficial] adjectives, to control the footage editing, almost creating inspection brigades. But what happens in the field is very hard to control. It is impossible to control if the person was paid more or less money. We can only control what happens back in the newsroom.

While describing the dynamics created when journalists are paid per diem fees by their news sources, most journalists recognised, as voiced above, that this poses an ethical dilemma. Interestingly, only one of the interviewed journalists called it bribery, using the word clearly:

Journalists are poorly paid. Anyone can easily bribe them... I don't like this and try not to participate. ... I want to be the best I can in my profession, ... so I try to stay away from these practices. I try to raise this issue in many journalists' meetings. Journalists have to avoid this bribing. 
There are a few media companies that pride themselves for somehow having found ways of avoiding the pressure caused by the dynamics of imbalanced power between politicians and journalists. Some private media opted for budgeting a specific amount, like the director of a private radio explains:

We pay all transportation costs here. We have this daily fund so that the journalists can use to go out on assignments... But most of these events take place in Bissau... If journalists are paid these per diems, the information tends to be biased... We try to avoid this bias and that is why this radio is one of Guinea's most reliable.

Another radio station, as its vice-director explains, opted for paying journalists higher salaries. That is feasible, however, because this radio is owned by the Catholic Church, so their sustainability is not dependent on government budget or advertising revenues:

The biggest difficulty in Guinea-Bissau is the low salaries and how journalists are lured to ignore deontology of journalism... they are influenced by money... being a Catholic radio we cannot fall into this situation, we cannot be corrupted... so we are well paid here... the minimum wage here is $€ 150 \ldots$ so we can practice free journalism here... a low salary can compromise this freedom.

In $O$ Democrata, a newspaper founded by the president of the journalists' association, the strategy encompassed a smaller body of staff with higher salaries and university degrees. The minimum wage there is 60000 CFA (US\$110), and the reporters are forbidden from accepting per diems. Besides, the newspaper is trying to develop a network of regional freelancers who would work as local correspondents, paid 10000 CFA (US\$18) per piece. The newspaper's director explains:

Some time ago a building collapsed in Cacheu. As I often provide journalism training in many community radios in the country, I know several young people whom I've worked with... As there was no means for transportation there, I called people in Cacheu, and asked a former student if he could cover it for us... so I gave him some instructions... and we ended up having detailed reporting of the accident because he was there and knew the place and the people... so this is how we manage to get closer to people... Having this network of correspondents helps us to avoid the per diem system.

Journalists who work as correspondents for foreign media affirm that they take a step away from accepting monetary incentives. A correspondent for the BBC explained that they cannot be involved in that "game" as it would cost them their job. Working for the international press also allows journalists to be impartial. This broadcast journalist, who works for both national media and Portuguese media (details were purposely omitted), admits that the coverage is different for the two media outputs: 
[Journalist:] When you work for international media, you have to be precise, and explain things more in-depth.

[Interviewer:] So, let's say, if it was election time, and you would report from a poorly attended rally. For the Portuguese media, could you tell that the rally was nearly empty?

[Journalist:] Exactly, I would use that as an opening line. ...

[Interviewer:] But for the national coverage, would you say that the rally was well attended?

[Journalist:] That's true, I would. It is complicated, but these are the rules of the game. Nobody is perfect and I am not saying I'm not a sinner in my profession.

These accounts demonstrate that the control and pressure from the political class change and impact the creation of knowledge and understanding of the events through journalism coverage. In this sense, national and international audience access to different epistemology and narration of events.

\section{The structural problems of journalism and initiatives of change}

The problematic dependency that sustains the relationship between journalists and politicians in Guinea-Bissau is, as argued, bound by this acceptance of the per diem fees, but this is far from being the only cause of the deep structural problems that the media face. The lack of a viable national economy and the context of political instability do not bring signs of a brighter future for journalism. There are severe limitations to the production, content, and consumption of news across all sectors. In 2014, UNESCO estimated an adult literacy rate of $45.58 \%$ and a youth literacy rate of $60.4 \%$. For this reason, newspaper sales are low, and an unappealing platform for advertisers. With marginal advertising revenues and income from low circulation, newspapers struggle for financial sustainability; the state-owned newspaper Nô Pintcha, for example, has a circulation of five hundred copies per week. The most relevant medium in Guinea-Bissau is the radio that, in the period post-independence, during conflicts and coups, becomes the main, if not the only, source of news. The broadcasters, however, are plagued by obsolete technology, unrepaired transmitters, neglected archives, and an unreliable power supply.

Although most media have some presence online, the digital divide is also a problem. The International Telecommunication Union, the specialised agency of the United Nations, estimates that the percentage of internet users in Guinea-Bissau was 3.9\% in 2017. While a growing number, this penetration rate represents a small fraction of the population, mostly concentrated in urban areas. The Wi-Fi supply is limited, but the 3G technology provided by mobile operators for smartphones is more reliable yet, also limited to an elite who can afford it. 
Another problem identified by the journalists is the limited reach in news production and consumption. The majority of the media is located in Bissau and, with a scarce budget to pay local correspondents or to send reporters to the provinces, the news contents are mostly centralised on sources from the capital, and a significant extension of the territory is rarely featured in the news. Further, most broadcasters, including the national television, do not have the technological capacity to reach the rural areas. The director of a private newspaper revealed his plans to overcome the problem of the news catering mostly to an urban Portuguese-speaking minority; they have been applying a proximity strategy with the collaboration of correspondents and by publishing more photography in its pages trying, this way, to promote the sales in smaller villages, where the literacy rates are significantly low. In his words,

[In the villages, people] won't buy the newspaper every day to read news from Bissau, about politics and parties. A newspaper costs 500CFA francs (US\$0.88)... it's as much as a kilo of rice, right?... So we need a different strategy... We have to reach out to people... If people can relate to the news, you will want to buy and keep the newspaper. So what we have to do to sell more is to have local correspondents, who would report on local stories, local people, and not just politics.

Most of the journalists who contributed to this research have referred to the lack of education and training that shadows the media sector as a critical reason for the prevalence of corruption within journalism. Although some journalists took a higher education degree in Bissau or abroad, a significant amount of workers has accessed the profession lacking this scholarly background. The participants referred to these journalists in a variety of terms: amateurs, empirical, self-proclaimed journalists, who use journalism as a platform to access a much better-paid employment as a press officer, in some cases even accumulating both jobs. This situation increases the chances of collusion and corruption between media and authorities, and to widespread militant and biased news content.

The lack of education and the unregulated access to the profession were some of the key points raised during the national meeting of journalists that I observed. The recently created association of journalists OJGB, who promoted the meeting, seeks to review the existing media law, professional accreditation criteria and to reinforce or rewrite the national codes of conduct. The legislative framework was referred to as a copy of the Portuguese media law, with little applicability to the Guinea-Bissauan context.

Although there are a few institutional bodies in Guinea-Bissau set out to protect journalism and freedom of the press, they were perceived as ineffective or inoperative. The national media council (Conselho Nacional de Comunicação Social) is an independent regulator, created to monitor partiality and to protect the sector from pressure and abuse, however, with a non-binding opinion. Additionally, 
there is the union of journalists (SINJOTECS) that confirms the professional accreditation. During the time of my research, this union was often referred by the participants as inoperative.

Journalists often mentioned access to ethical training as essential. Some of the reporters interviewed were also lecturers at the date, and they have recognised that, despite highlighting the importance of ethical conducts and professionalism during classes, the practice is often distant from the theory. As this journalist and lecturer clarifies,

We teach what is published in handbooks but then the reality dictates otherwise. We explain that each country has its particularities; and we also teach about the war between the two classes... The politicians try to control the media, and the media are a political tool by excellence. They know about the importance of the media; and the media, we do try to put into practice what we learn that journalism should be. But there are many conflicting interests. We do have to make an effort but, in an African context, sometimes you can even lose your life because of this battle for press freedom.

Yet journalists remain hopeful about the potential of this press association to succeed and contribute to the improvement of the media environment in Guinea-Bissau. Through email follow-ups, I have been informed that the association has re-written in 2017 the national deontological code of journalists, which has been informally adopted by most newsrooms. The document, however, awaits official ratification by the National Assembly, which has not been sitting since 2015 due to the political and institutional crisis.

\section{Conclusion}

Paying and accepting per diem fees is a deep-rooted habit in Guinea-Bissauan journalism. The journalists interviewed described this as a commonly established practice, mentioning that these payments are fixed and occur openly and lawfully. They were aware, however, of the ethical dilemma that it raises, and recognised the impact that these payments have on their professional integrity. Only one reporter assumed this practice as bribery, and many of the informants in this study admitted receiving these payments, despite resenting its consequences. The research in other countries has connected precarious work conditions as fundamental reasons to why bribery and corruption prevails. Thus, monetary incentives in journalism become culturally entrenched, despite the ethical consequences. In the Guinea-Bissauan case, there have been self-regulatory efforts amongst the media sector to discourage and prevent the acceptance of these payments, and the recently reformed Deontological Code affirms the need for journalists to 'reject all forms of bribery and pressure', despite not providing a specific description of what payments they consider to fall under this category. 
Given, however, the economic distress and the recognition of these extra forms of income as inevitable, it is likely that the practice will continue. This example from Guinea-Bissau raises a broader discussion on media ethics that the research on monetary incentives in journalism has been exploring. Part of the discussion advocates that the term 'bribery' should be reconsidered since it might relate merely to a Western ethics perspective. Wasserman (2008) suggested a 'hybrid ethical framework' when considering brown envelopes, encapsulating the notions of fairness and credibility but also acknowledging the precariousness under which most African journalists operate. If a different ethical setting for African journalism might not be consensual amongst scholars, what is generally agreed is that the habit compromises journalistic integrity, as most participants in this research explained. Journalists demonstrated distress for not having a chance to conduct investigative reporting, accomplishing their perceived responsibility in raising awareness for human rights issues (SampaioDias 2016), and for contributing to a healthier public sphere by holding power into account. With limited financial resources and with an extreme dependency on per diem for subsistence, journalists become an easy target for military and political authorities to control.

In this sense, this paper argued that the main distinction between the practices of bribing journalists and paying them per diem is that these stipends are legitimised, expected and commonly accepted in the sector. Journalists, however, admit that this is damaging to their integrity, and that the practice prevents an unhealthy and limited circulation of political ideas. Like bribery, the acceptance of per diem consents the establishment of an informal contract between journalists and sources, who expect beneficial coverage, and threat journalistic independence. This subtle form of control, in its turn, characterises Guinea-Bissauan journalism, but it is not exclusive to this country, as other scholars documented. The sense of legality of the per diem also legitimises a form of control that is excused from accountability. For this reason, per diem fees, I argue, should not be dismissed as a minor form of bribery, or as an inevitable practice within susceptible contexts of poverty. Scholars, press freedom defenders and policymakers should not oversee the ethical implications of this practice for press freedom, journalists' security and democratisation and bring this forward to the agenda of debate.

Finally, this research provided the chance to amplify the voices of the journalists from an understudied country in the field of Journalism. It documented Guinea-Bissau's media scene that is troubled by limited financial resources, unregulated access to the profession, insubstantial education and training, obsolete technology and limited geographical reach. As for the news, militant and propaganda contents prevail, fuelled by the pressure from authorities and by the indirect mechanism of control established with the payment of monetary incentives to journalists. Despite a few initiatives towards improvement, including the creation of an association of journalists that aims to review the national legislative framework for journalism, the continuous political crisis and instability, paralleled 
by the journalism sector's fragility, hinders this progress and contribute to a slow, stagnant, and problematic change.

Table 1 - Differences and similarities between Brown Envelope payments and Per Diem payments

\begin{tabular}{|c|c|}
\hline Brown Envelope Payments & Per Diem Payments \\
\hline $\begin{array}{l}\text { Variety of metaphors and euphemisms to } \\
\text { conceal corruption }\end{array}$ & Institutionally recognised name \\
\hline Occurs on a personal level & Occurs on an institutional level \\
\hline $\begin{array}{c}\text { Some degree of confidentiality, variable } \\
\text { amount }\end{array}$ & Agreed, expected and tariffed amount \\
\hline Illegitimate, corrupt practice & Official and legitimised practice \\
\hline $\begin{array}{c}\text { Establishes an informal contract between } \\
\text { journalists and sources for positive } \\
\text { coverage }\end{array}$ & $\begin{array}{c}\text { Establishes an informal contract between } \\
\text { journalists and sources for positive } \\
\text { coverage }\end{array}$ \\
\hline $\begin{array}{l}\text { Poses a challenge for journalistic } \\
\text { independence }\end{array}$ & $\begin{array}{l}\text { Poses a challenge for journalistic } \\
\text { independence }\end{array}$ \\
\hline Subtle form of control and censorship & Subtle form of control and censorship \\
\hline
\end{tabular}

\section{NOTES}

1. All interviews and focus group discussions were conducted, recorded, and transcribed professionally in Portuguese. The used excerpts cited in this paper were translated into English by the author.

2. This is a project that aims at developing a country-scale management strategy within an interdisciplinary working group dedicated to primate conservation. The project encompasses environment and conservation training with journalists in Guinea-Bissau.

3. The interviews and focus group participants included the representations from private and public print media (O Democrata, Nô Pintcha), state and private broadcasters (Televisão da Guiné Bissau, Radiodifusão Nacional, Rádio Bombolom, Rádio Pindjiguiti, Rádio Jovem, 
Capital FM, Sol Mansi), community media (Rádio Papagaio, Rádio Bijagós, Rádio Orango) and press officers from the national bio-diversity institute (IBAP).

\section{REFERENCES}

Al Jazeera. 2015. "Bribes And Brown Envelopes: Nigeria's 'Journalists'". 27 December 2015. Aljazeera.com. https://www.aljazeera.com/programmes/listeningpost/2015/12/bribes-brownenvelopes-nigeria-journalists-151227175941010.html

Cagé, Julia. 2015. "The Economics of African Media”, in Monga, Célestin, and Justin Yifu Lin, eds. The Oxford Handbook of Africa and Economics: Volume 1: Context and Concepts. OUP Oxford.

Chabal, Patrick, and Toby Green. 2016. Guinea-Bissau: Micro-state to'narco-state'. Hurst

Dirbaba, Birhanu Olana. 2010. "The growing influence of bribery in Ethiopian journalism." African Communication Research 3, no. 3: 475-496.

Eke, Ikechukwu Williams. 2014. "Brown envelope syndrome and the future of journalism in Nigeria." International Interdisciplinary Journal of Scientific Research 1, no. 1.

Ekeanyanwu, Nnamdi and Nkechi Obianigwe. 2010. "Perception of Lagos-based journalists on brown envelope syndrome (BES) in the coverage of news events in Nigeria”. International Journal of Social Sciences and Humanities Review, 1(1)

Ekeanyanwu, Nnamdi and Nkechi Obianigwe. 2012. "The Nigerian Press, Brown Envelope Syndrome (BES) and Media Professionalism: The Missing Link." Journalism and Mass Communication 2 (4), 515-529.

Elahi, Manzur. 2013. "They are Not Different From Others: Ethical Practices and Corruption in Bangladeshi Journalism." Journal of Mass Media Ethics 28 (3), 189-202.

Fair, Jo Ellen. 2013. "Democratization by Boilerplate. National Media, International Norms, and Sovereign Nation Building in Postwar Liberia". In Global media ethics: Problems and perspectives, edited by Stephen Ward. John Wiley \& Sons

Freedom House. 2014. "Freedom of the Press Report 2014. Guinea-Bissau”. Accessed September 21. https://freedomhouse.org/report/freedom-press/2014/guinea-bissau

Grätz, Tilo. 2015. "Media Development, Censorship and Working Conditions of Journalists in the Republic of Benin (West Africa)." In Media Freedom and Right to Information in Africa, edited by Luca Bussotti, Miguel de Barros and Tilo Grätz, 13-29.

International Telecommunications Union. 2017. Measuring the Information Society Report 2017 
Kasoma, Twange. 2009. "Development reporting as a crumbling tower? Impact of brown envelope journalism on journalistic practice in Zambia and Ghana." Global Media Journal-African Edition 3, no. $1: 18-32$.

Kruckeberg, A., and Katerina Tsetsura. 2003. A Composite Index by Country Of Variables Related to the Likelihood Of the Existence Of 'Cash for News Coverage'. Institute for Public Relations, Gainesville, Florida.

Lodamo, Berhanu, and Terje S. Skjerdal. 2009. "Freebies and brown envelopes in Ethiopian journalism." Ecquid Novi 30 (2): 134-154.

Loo, Eric. 2005. "Filipino journalists speak out and pay the price." Media Development, 52 (4).

Lopes, António Soares. 2015. Os Media na Guiné-Bissau. [Media in Guinea-Bissau]. Bissau: Edições Corubal/UE/PAANE

Mendy, Peter Karibe and Lobban Jr., Richard. 2013. Historical Dictionary of the Republic of Guinea-Bissau. Plymouth, MA: Scarecrow Press. Fourth edition.

Ndangam, Lilian. 2006. "Gombo': Bribery and the corruption of journalism ethics in Cameroon." Ecquid Novi 27 (2): 179-199.

Ndangam, Lilian. 2009. "All of us have taken gombo. Media pluralism and patronage in Cameroonian journalism.” Journalism 10(6): 819-842

Ngangum, Peter Tiako. 2016 "Cash and Gifts for Coverage: Bribery and Corruption of Journalism Ethics in Cameroon." In Controversial matters on media ethics, edited by Luis Guadarrama Rico. 71-90. Dykinson

Nwabueze, Chinenye. 2010. "Brown envelopes and the need for ethical reorientation: perceptions of Nigerian journalists". African Communication Research, 3 (2), 43-51

Okoro, Nnanyelugo, and Blessing Chinweobo-Onuoha. 2013. “Journalists' Perception of Brown Envelope Syndrome and its implications for Journalism Practice in Nigeria”. Covenant Journal of Communication 1(2), 130-144

Onyebadi, Uche, and Fawaz Alajmi. 2016. "Gift solicitation and acceptance in journalism practice: An assessment of Kuwaiti journalists' perspective." Journalism 17 (3): 348-365.

Ostheimer, Andrea E. 2001. "The structural crisis in Guinea-Bissau's political system." African Security Review 10 (4), 45-58.

Pfeiffer, James. 2003. "International NGOs and primary health care in Mozambique: the need for a new model of collaboration." Social Science \& Medicine 56 (4), 725-738.

Reporters Without Borders (RSF). 2017. “Guinea-Bissau suspends Portuguese public radio and TV broadcasts". July 4. https://rsf.org/en/news/guinea-bissau-suspends-portuguese-public-radio-and-tv$\underline{\text { broadcasts }}$ 
Reporters Without Borders (RSF). 2018. “2018 World Press Freedom Index. Guinea-Bissau”. Accessed September 21. https://rsf.org/en/guinea-bissau

Ridde, Valéry. 2010. "Per diems undermine health interventions, systems and research in Africa: burying our heads in the sand." Tropical Medicine \& International Health, 00-00.

Ristow, Bill. 2010. "Cash for coverage: Bribery of journalists around the world." Washington: Center for International Media Assistance

Sampaio-Dias, Susana. 2016. Reporting Human Rights. New York: Peter Lang

Sanders, Karen. 2003. Ethics and journalism. Sage

Sanner, Terje, and Johan Sæbø. 2014. "Paying per diems for ICT4D project participation: A sustainability challenge." Information Technologies \& International Development 10 (2)

Skjerdal, Terje. 2010. "Research on brown envelope journalism in the African media." African Communication Research 3 (3), 367-406.

Skjerdal, Terje. 2018. "Brown envelope journalism: The contradiction between ethical mindset and unethical practice.' In Newsmaking cultures in Africa, edited by Hayes Mabweazara, Palgrave Macmillan, London

Vincent, Léonard. 2007. "Guinea-Bissau: Cocaine and coups haunt gagged nation." Paris: Reporters without Borders. Accessed September 21.https://rsf.org/sites/default/files/rapport guineebissau en.pdf

Wahl-Jorgensen, Karin and Bernadette Cole. 2008. "Newspapers in Sierra Leone: A case study of conditions for print journalism in a postconflict society". Ecquid Novi: African Journalism Studies, 29(1), $1-20$

Wasserman, Herman (2008). "Media ethics and human dignity in the Postcolony". In Media ethics beyond borders, edited by Stephen J.A. Ward and Herman Wasserman. Johannesburg: Heinemann. 